\title{
SCREENING HEMP (CANNABIS SATIVA L.) BIOMASS AND CHEMICAL COMPOSITION AS INFLUENCED BY SEED RATE AND GENOTYPE
}

\author{
Zofija Jankauskiene $^{1}$, Elvyra Gruzdeviene ${ }^{1}$, Semjons Ivanovs ${ }^{2}$, Ernestas Maumevicius ${ }^{3}$ \\ ${ }^{1}$ Upyte Experimental Station of the Lithuanian Research Centre for Agriculture and Forestry; \\ ${ }^{2}$ Latvia University of Agriculture; ${ }^{3}$ Aleksandras Stulginskis University \\ soja@upyte.lzi.lt, semjons@apollo.lv
}

\begin{abstract}
Nowadays the industrial hemp (Cannabis sativa L.) becomes an attractive plant due to its multiple uses. In 2016 the cultivated area of this plant in Lithuania was close to 2.5 thousand hectares. The main interest areas in this plant are valuable seeds, fibre and hurds, cannbinoides and essential oils, and, of course, energy potential. The investigation of hemp biomass and chemical composition was carried out at the Upyte Experimental Station of LRCAF in 2014. The data showed that both factors had significant influence on hemp fresh and totally dry above-ground biomass. Notwithstanding that the amount of $\mathrm{C}, \mathrm{N}, \mathrm{C} / \mathrm{N}, \mathrm{S}, \mathrm{K}, \mathrm{Na}$, crude ash and the calorific value were evaluated, the tested factors did not show any significant influence on the tested parameters (chemical composition).
\end{abstract}

Keywords: hemp biomass, chemical composition, calorific value.

\section{Introduction}

Nowadays we know the industrial hemp (Cannabis sativa L.) as a plant of multiple uses. Nevertheless, over many centuries hemp was used mainly as a textile plant [1-4]. Also hemp fiber could be widely used in paper, composites, agriculture, automotive, construction, isolation, medicine, etc. [5-8].

The interest in this plant is growing not only in the Baltic countries [9], but overall the world also $[2 ; 10]$.

Hemp plants are growing relatively rapidly, thus enough huge amount of biomass could be produced under certain growing conditions. In the previous our trials, in 2010, plants of the tested hemp genotypes gave around $10.5 \mathrm{t} \cdot \mathrm{ha}^{-1}$ of dry biomass (DM), and $11.5 \mathrm{t} \cdot \mathrm{ha}^{-1}$ in 2011. Cultivars

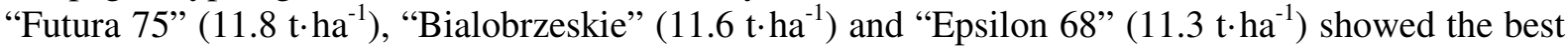
results of the dry mass yield in 2010, while in 2011, the most productive were the cultivars "Beniko" $\left(13.1 \mathrm{t} \cdot \mathrm{ha}^{-1}\right)$, and "Futura 75 " (12.3 tha $\left.\mathrm{ha}^{-1}\right)$ [10].

The biomass is described as "plant material derived from the reaction between $\mathrm{CO} 2$ in the air, water and sunlight, via photosynthesis, to produce carbohydrates that form the building blocks of biomass [11].Biomass consists of different amounts of cellulose, hemicellulose, lignin and a small amount of other compounds, thus in many references the hemp chemical composition is describe generally as the amount of cellulose, holocellulose, and lignin, and very rarely the chemical composition in the elements is presented.

The aim of the paper is the presentation of some elements of chemical compositions of hemp biomass as influenced by the genotype and seed rate, as well as the evaluation of possible calorific value of hemp biomass.

\section{Materials and methods}

The investigation of the hemp plant morphological parameters was carried out at the Upyte Experimental Station of the Lithuanian Research Centre for Agriculture and Forestry in 2014. The soil - Eutri-Endohypogleyic Cambisol, CMg-n-w-eu [12].

The scheme of bi-factorial trial, plot size, etc. were described in previous paper [7].

For chemical analyses the samples were dried at $65 \pm 5^{\circ} \mathrm{C}$. Prior analyses the samples were ground by an ultracentrifugal mill ZM 200 (Retch) using sieves of $2 \mathrm{~mm}$ mesh size.

The $\mathrm{C}, \mathrm{N}$ and $\mathrm{S}$ contents in the plant samples were determined simultaneously by a dry combustion method (Dumas) using a fully automatic analyser Vario EL III (Elementar, Germany). This method is based on combustion at $\sim 900{ }^{\circ} \mathrm{C}$.

$\mathrm{Na}, \mathrm{K}$ were determined by atomic absorptiometry using AAnalyst 200 (Perkin Elmer). 
The ash content was determined by the standard procedure (LST EN 14775). This method covers the determination of ash, expressed as the percentage of residue remaining after dry oxidation at 550 .

The calorific value was measured using an IKA bomb calorimeter (C 200, Germany).

For statistical data evaluation the statistical software developed in the Lithuanian Institute of Agriculture was used, the ANOVA method was applied [13].

Meteorological conditions (Fig. 1) were described in the previous paper [7].
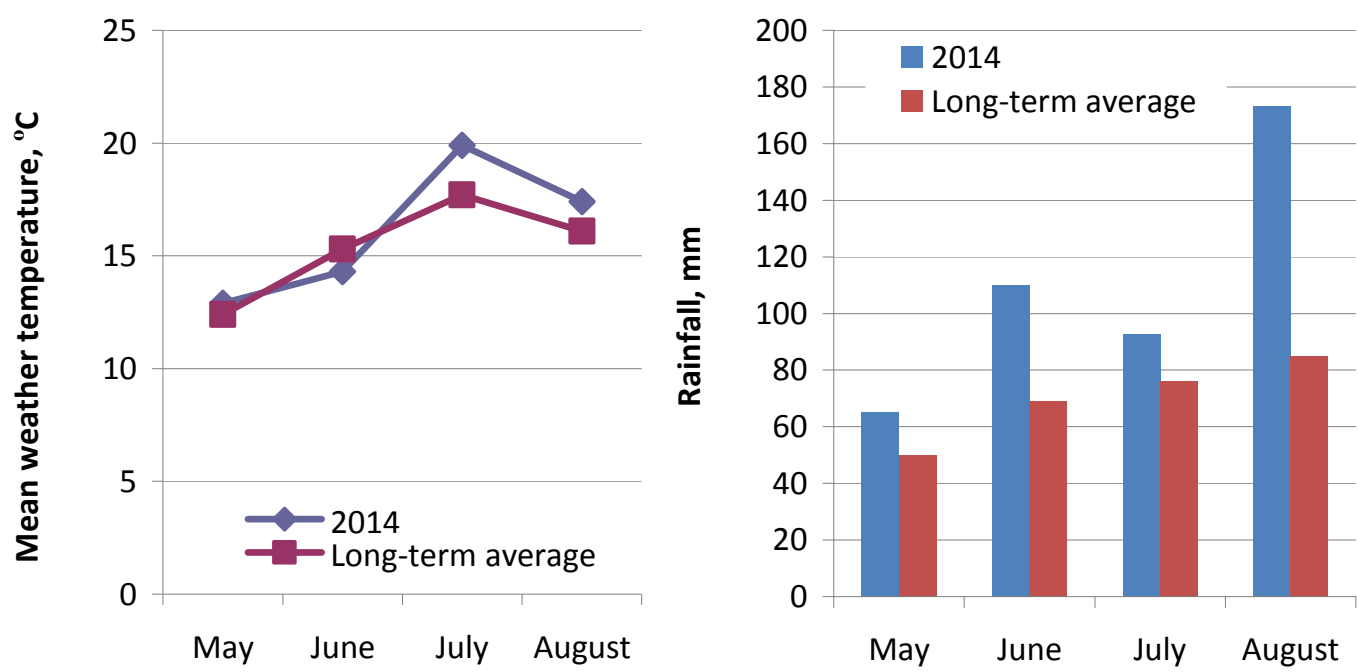

Fig. 1. Mean weather temperature and precipitation during hemp growing period

\section{Results and discussion}

In 2014, the fresh hemp biomass yield (stems, leaves, inflorescences and seeds) was enough high $\left(30.2-48.2 \mathrm{t} \cdot \mathrm{ha}^{-1}\right)$ (Table 1). The tested parameters showed a significant influence on this parameter. The yield of variety Bialobrzeskie was significantly higher $\left(43.7 \mathrm{t} \cdot \mathrm{ha}^{-1}\right)$ than that of variety USO 31 $\left(33.3 \mathrm{t} \cdot \mathrm{ha}^{-1}\right)$. Hemp sown at a higher seed rate $\left(70\right.$ calorific $\left.^{-1}\right)$ produced higher fresh biomass yield $\left(42.4 \mathrm{t} \cdot \mathrm{ha}^{-1}\right)$ than that $\left(3.45\right.$ calorific $\left.^{-1}\right)$ when sowing at the rate of 45 calorific $^{-1}$.

Table 1

Hemp fresh biomass yield (calorific ${ }^{-1}$ ) as influenced by genotype and seed rate

\begin{tabular}{|c|c|c|c|}
\hline \multirow{2}{*}{ Variety (Factor A) } & \multicolumn{2}{|c|}{ Seed rate (Factor B) } & \multirow{2}{*}{ Mean for Factor A } \\
\cline { 2 - 4 } & $\mathbf{4 5} \mathbf{~ k g} \cdot \mathbf{h a}^{-\mathbf{1}}$ & $\mathbf{7 0} \mathbf{~ h a}$ & \\
\hline USO 31 & 30167 & 36476 & $33321^{*}$ \\
\hline Bialobrzeskie & 38905 & 48429 & $43667^{*}$ \\
\hline Mean for Factor B & $34536^{*}$ & $42452^{*}$ & - \\
\hline $\mathrm{LCD}_{05}\left(\right.$ variety) $=3059 \mathrm{LCD}_{05}($ seed rate $)=3059 \mathrm{LCD}_{05}($ variety x seed rate) $=5298$ \\
\hline
\end{tabular}

* - significant at 0.05 probability level

The moisture content in the fresh biomass was between 63-66 \% (Table 2). Statistical analysis did not show any significant differences in it.

Totally the dry hemp biomass yield was between 10.0 and $16.9 \mathrm{t} \cdot \mathrm{ha}^{-1}$ (Table 3). Both tested factors showed a significant influence on this parameter. The dry biomass yield of variety Bialobrzeskie was significantly higher $\left(15.5 \mathrm{t} \cdot \mathrm{ha}^{-1}\right)$ than that of variety USO $31\left(11.8 \mathrm{t} \cdot \mathrm{ha}^{-1}\right)$.

Hemp sown at a higher seed rate $\left(70\right.$ calorific $\left.^{-1}\right)$ produced higher dry biomass yield $\left(15.2 \mathrm{t} \cdot \mathrm{ha}^{-1}\right)$ than that (12.1 calorific $^{-1}$ ) when sowing at the rate of 45 calorific $^{-1}$.

The carbon content found in our trials (Table 4) was slightly higher (44\%) than that found in the trials conducted in 2008-2009 where the carbon content in hemp plants was between $38 \%$ and $41 \%)[14]$. Neither genotype nor seed rate showed the influence on the carbon content in hemp biomass. 
Table 2

Moisture content ( \%) in hemp fresh biomass yield as influenced by genotype and seed rate

\begin{tabular}{|c|c|c|c|}
\hline \multirow{2}{*}{ Variety (Factor A) } & \multicolumn{2}{|c|}{ Seed rate (Factor B) } & \multirow{2}{*}{ Mean for Factor A } \\
\cline { 2 - 3 } & $\mathbf{4 5} \mathbf{~ k g} \cdot \mathbf{h a}^{-\mathbf{1}}$ & $\mathbf{7 0 ~} \mathbf{~ g} \cdot \mathbf{h a}^{-\mathbf{1}}$ & 64.6 \\
\hline USO 31 & 66.4 & 62.7 & 64.4 \\
\hline Bialobrzeskie & 63.8 & 65.1 & - \\
\hline Mean for Factor B & 65.1 & 63.9 & \\
\hline
\end{tabular}

$\mathrm{LCD}_{05}($ variety $)=2.22 \mathrm{LCD}_{05}($ seed rate $)=2.22 \mathrm{LCD}_{05}($ variety $\mathrm{x}$ seed rate $)=3.85$

Hemp dry biomass yield (calorific ${ }^{-1}$ ) as influenced by genotype and seed rate

\begin{tabular}{|c|c|c|c|}
\hline \multirow{2}{*}{ Variety (Factor A) } & \multicolumn{2}{|c|}{ Seed rate (Factor B) } & \multirow{2}{*}{ Mean for Factor A } \\
\cline { 2 - 3 } & $\mathbf{4 5} \mathbf{~ k g \cdot h \mathbf { h a } ^ { - 1 }}$ & $\mathbf{7 0 ~} \mathbf{~ k g} \cdot \mathbf{h a}^{-1}$ & \\
\hline USO 31 & 10021 & 13624 & $11,822^{*}$ \\
\hline Bialobrzeskie & 14205 & 16879 & $15542^{*}$ \\
\hline Mean for Factor B & $12113^{*}$ & $15252^{*}$ & - \\
\hline $\mathrm{LCD}_{05}\left(\right.$ variety) $=1177 \mathrm{LCD}_{05}$ (seed rate) $=1177 \mathrm{LCD}_{05}$ (variety x seed rate) $=2038$ \\
\hline
\end{tabular}

$*$ - significant at 0.05 probability level;

Table 4

Carbon content ( \% DM) in hemp biomass as influenced by genotype and seed rate

\begin{tabular}{|c|c|c|c|}
\hline \multirow{2}{*}{ Variety (Factor A) } & \multicolumn{2}{|c|}{ Seed rate (Factor B) } & \multirow{2}{*}{ Mean for Factor A } \\
\cline { 2 - 3 } & $\mathbf{4 5} \mathbf{~ k g} \cdot \mathbf{h a}^{-1}$ & $\mathbf{7 0 ~} \mathbf{~ k g} \cdot \mathbf{h a}^{-1}$ & 44.75 \\
\hline USO 31 & 44.6 & 44.9 & 44.42 \\
\hline Bialobrzeskie & 44.7 & 44.13 & - \\
\hline Mean for Factor B & 44.65 & 44.52 & (variety x seed rate) $=0.400$ \\
\hline \multicolumn{2}{|c|}{$\mathrm{LCD}_{05}\left(\right.$ variety) $=0.231 \mathrm{LCD}_{05}($ seed rate $)=0.231 \mathrm{LCD}_{05}$. }
\end{tabular}

The nitrogen content in hemp biomass was between 0.96-1.20\% (Table 5). Statistical analysis did not show any significant differences in it.

Nitrogen content ( \% DM) in hemp biomass as influenced by genotype and seed rate

\begin{tabular}{|c|c|c|c|}
\hline \multirow{2}{*}{ Variety (Factor A) } & \multicolumn{2}{|c|}{ Seed rate (Factor B) } & \multirow{2}{*}{ Mean for Factor A } \\
\cline { 2 - 3 } & $\mathbf{4 5} \mathbf{~ k g} \cdot \mathbf{h a}^{-1}$ & $\mathbf{7 0 ~} \mathbf{~ g} \cdot \mathbf{h a}^{-1}$ & 1.03 \\
\hline USO 31 & 1.06 & 0.99 & 1.03 \\
\hline Bialobrzeskie & 0.85 & 1.20 & - \\
\hline Mean for Factor B & 0.96 & 1.10 & 0.284 \\
\hline $\mathrm{LCD}_{05}($ variety $)=0.164 \mathrm{LCD}_{05}($ seed rate $)=0.164 \mathrm{LCD}_{05}($ variety x seed rate $)=0$.
\end{tabular}

The ratio between the carbon and nitrogen content in hemp biomass was between 39.2 and $52.6 \%$ (Table 6), but the influence of the tested factors was not established.

Ratio between carbon and nitrogen content in hemp biomass as influenced by genotype and seed rate

\begin{tabular}{|c|c|c|c|}
\hline \multirow{2}{*}{ Variety (Factor A) } & \multicolumn{2}{|c|}{ Seed rate (Factor B) } & \multirow{2}{*}{ Mean for Factor A } \\
\cline { 2 - 3 } & $\mathbf{4 5} \mathbf{~ k g ~ h a}^{-\mathbf{1}}$ & $\mathbf{7 0 ~} \mathbf{~ g} \cdot \mathbf{h a}$ & \\
\hline USO 31 & 42.58 & 46.76 & 44.67 \\
\hline Bialobrzeskie & 52.6 & 39.21 & 45.90 \\
\hline Mean for Factor B & 47.59 & 42.98 & - \\
\hline $\mathrm{LCD}_{05}\left(\right.$ variety) $=7.132 \mathrm{LCD}_{05}($ seed rate $)=7.132 \mathrm{LCD}_{05}($ variety $\mathrm{x}$ seed rate $)=12.353$ \\
\hline
\end{tabular}

The sulphur content in hemp biomass did not differ between the treatments (Table 7). 
Sulphur content ( \% DM) in hemp biomass as influenced by genotype and seed rate

\begin{tabular}{|c|c|c|c|}
\hline \multirow{2}{*}{ Variety (Factor A) } & \multicolumn{2}{|c|}{ Seed rate (Factor B) } & \multirow{2}{*}{ Mean for Factor A } \\
\cline { 2 - 3 } & $\mathbf{4 5} \mathbf{~ k g} \cdot \mathbf{h a}^{-\mathbf{1}}$ & $\mathbf{7 0} \mathbf{~ k g} \cdot \mathbf{h a}$ & \\
\hline USO 31 & 0.14 & 0.13 & 0.14 \\
\hline Bialobrzeskie & 0.13 & 0.15 & 0.14 \\
\hline Mean for Factor B & 0.14 & 0.14 & - \\
\hline $\mathrm{LCD}_{05}\left(\right.$ variety) $=0.015 \mathrm{LCD}_{05}$ (seed rate) $=0.015 \mathrm{LCD}_{05}$ (variety x seed rate) $=0.026$ \\
\hline
\end{tabular}

The potassium content in hemp biomass was between 1.27 and $1.59 \%$ (Table 8). Statistical analysis did not show any significant differences in it.

Table 8

Potassium content ( \% DM) in hemp biomass as influenced by genotype and seed rate

\begin{tabular}{|c|c|c|c|}
\hline \multirow{2}{*}{ Variety (Factor A) } & \multicolumn{2}{|c|}{ Seed rate (Factor B) } & \multirow{2}{*}{ Mean for Factor A } \\
\cline { 2 - 4 } & $\mathbf{4 5} \mathbf{~ k g} \cdot \mathbf{h a}^{-\mathbf{1}}$ & $\mathbf{7 0} \mathbf{~ k g} \cdot \mathbf{h a}$ & \\
\hline USO 31 & 1.59 & 1.27 & 1.43 \\
\hline Bialobrzeskie & 1.45 & 1.52 & 1.48 \\
\hline Mean for Factor B & 1.52 & 1.39 & - \\
\hline $\mathrm{LCD}_{05}($ variety $)=0.082 \mathrm{LCD}_{05}($ seed rate $)=0.082 \mathrm{LCD}_{05}($ variety x seed rate $)=0.142$ \\
\hline
\end{tabular}

The content of sodium in hemp biomass was very low - 0.65-0.07\% (Table 9). Any significant differences in the sodium content in hemp biomass were not found also.

Table 9

Sodium content ( \% DM) in hemp biomass as influenced by genotype and seed rate

\begin{tabular}{|c|c|c|c|}
\hline \multirow{2}{*}{ Variety (Factor A) } & \multicolumn{2}{|c|}{ Seed rate (Factor B) } & \multirow{2}{*}{ Mean for Factor A } \\
\hline & $45 \mathrm{~kg} \cdot \mathrm{ha}^{-1}$ & $70 \mathrm{~kg} \cdot \mathrm{ha}^{-1}$ & \\
\hline USO 31 & 0.067 & 0.069 & 0.068 \\
\hline Bialobrzeskie & 0.065 & 0.070 & 0.068 \\
\hline Mean for Factor B & 0.066 & 0.070 & - \\
\hline
\end{tabular}

The ash content is one of the major qualitative characteristics of biomass [15]. In our investigation it was really high - even 6.7-10.2 \% (Table 10), while other references report about rather lower ash content. The ash content of the pellets made of hemp biomass varied from 3.6 to $3.8 \%$ [16].

Ash content ( \% DM) in hemp biomass as influenced by genotype and seed rate

\begin{tabular}{|c|c|c|c|}
\hline \multirow{2}{*}{ Variety (Factor A) } & \multicolumn{2}{|c|}{ Seed rate (Factor B) } & \multirow{2}{*}{ Mean for Factor $\mathbf{A}$} \\
\hline & $45 \mathrm{~kg} \cdot \mathrm{ha}^{-1}$ & $70 \mathrm{~kg} \cdot \mathrm{ha}^{-1}$ & \\
\hline USO 31 & 13.5 & 6.74 & 10.12 \\
\hline Bialobrzeskie & 7.13 & 10.16 & 8.65 \\
\hline Mean for Factor B & 10.31 & 8.45 & - \\
\hline \multicolumn{4}{|c|}{$\mathrm{LCD}_{05}($ variety $)=1.706 \mathrm{LCD}_{05}($ seed rate $)=1.706 \mathrm{LCD}_{05}($ variety $\mathrm{x}$ seed rate $)=2.956$} \\
\hline
\end{tabular}

In the investigation in Latvia, the hemp stem average calorific value was $16.98 \mathrm{MJ} \cdot \mathrm{kg}^{-1} \pm 0.5 \%$ [15]. In the investigation in Lithuania, the average calorific value of the pellets maid of hemp biomass varied from 17.2 to $17.5 \mathrm{MJ} \cdot \mathrm{kg}^{-1} \mathrm{DM}$, and was close to the calorific value of some wood species [16].

Polish researches confirm that hemp biomass has great calorific value (about $19 \mathrm{MJ} \cdot \mathrm{kg}^{-1}$ ) and is an excellent feedstock for energy production [17].

In our investigation the calorific value of hemp biomass was close $18 \mathrm{MJ} \cdot \mathrm{kg}^{-1}$, and did not depend on the genotype and seed rate (Table 11). 
Calorific value $\left(\mathrm{kJ} \mathrm{kg}^{-1}\right)$ in hemp biomass as influenced by genotype and seed rate

\begin{tabular}{|c|c|c|c|}
\hline \multirow{2}{*}{ Variety (Factor A) } & \multicolumn{2}{|c|}{ Seed rate (Factor B) } & \multirow{2}{*}{ Mean for Factor A } \\
\cline { 2 - 3 } & $\mathbf{4 5} \mathbf{~ k g} \cdot \mathbf{h a}^{-\mathbf{1}} \cdot \mathbf{h a}$ & \\
\hline USO 31 & 17.50 & 18.10 & 17.80 \\
\hline Bialobrzeskie & 17.97 & 17.73 & 17.85 \\
\hline Mean for Factor B & 17.73 & 17.92 & - \\
\hline \multicolumn{2}{|c|}{$\mathrm{LCD}_{05}($ variety $)=0.139 \mathrm{LCD}_{05}($ seed rate $)=0.139 \mathrm{LCD}_{05}($ variety $\mathrm{x}$ seed rate $)=0.241$} \\
\hline
\end{tabular}

Calculations of the possible hemp calorific value harvest per ha show huge resources of energy $175477-299439 \mathrm{~kJ} \cdot \mathrm{ha}^{-1}$ (Table 12). The hemp biomass calorific value per ha depended on the genotype as well as on the seed rate - variety Bialobrzeskie had greater calorific potential $\left(277233 \mathrm{~kJ} \cdot \mathrm{ha}^{-1}\right)$, than USO $31\left(211127 \mathrm{~kJ} \cdot \mathrm{ha}^{-1}\right)$. Crops sown at higher seed rate $\left(70\right.$ calorific $\left.^{-1}\right)$ produced higher calorific potential $\left(273108 \mathrm{~kJ} \cdot \mathrm{ha}^{-1}\right)$ than that $\left(215252 \mathrm{~kJ} \cdot \mathrm{ha}^{-1}\right)$ sown at the seed rate of 45 calorific $^{-1}$.

Table 12

Calorific value $\left(\mathrm{kJ} \mathrm{ha}^{-1}\right)$ in hemp biomass as influenced by genotype and seed rate

\begin{tabular}{|c|c|c|c|}
\hline \multirow{2}{*}{ Variety (Factor A) } & \multicolumn{2}{|c|}{ Seed rate (Factor B) } & \multirow{2}{*}{ Mean for Factor $A$} \\
\hline & $45 \mathrm{~kg} \cdot \mathrm{ha}^{-1}$ & $70 \mathrm{~kg} \cdot \mathrm{ha}^{-1}$ & \\
\hline USO 31 & 175477 & 246777 & $211127 *$ \\
\hline Bialobrzeskie & 255027 & 299439 & $277233^{*}$ \\
\hline Mean for Factor B & $215252^{*}$ & $273108^{*}$ & - \\
\hline \multicolumn{4}{|c|}{$\mathrm{LCD}_{05}($ variety $)=19954.7 \mathrm{LCD}_{05}($ seed rate $)=19954.7 \mathrm{LCD}_{05}($ variety x seed rate $)=34562.6$} \\
\hline
\end{tabular}

\section{Conclusions}

Both factors (genotype and seed rate) had a significant influence on the hemp fresh and totally dry above-ground biomass yield as well as on the calorific value per ha. Notwithstanding that the amount of $\mathrm{C}, \mathrm{N}, \mathrm{C} / \mathrm{N}, \mathrm{S}, \mathrm{K}, \mathrm{Na}$, crude ash and the calorific value were evaluated, the tested factors did not show any significant influence on the tested parameters (chemical composition).

\section{References}

1. Horne M.R.L. Bast fibres: hemp cultivation and production. Handbook of Natural Fibres. Volume 1: Types, Properties and Factors Affecting Breeding and Cultivation (Edited by R. Kozlowski), Cambridge, UK, Woodhead Publishing Series in Textiles, 2012, pp. 114-145.

2. Amaducci S., Gusovius H.-J. Hemp - cultivation, extraction and processing. Industrial Application of Natural Fibres: Properties and Technical Application (Ed. Müssing J.), A JohnWiley \& Sons, UK, 2010, pp. 109-134.

3. Мигаль М.Д. Біологія луб'яних волокон конопель (Biology of hemp fibres). Суми: ТОВ „ТД Папірус", 2011, 390 р. (In Ukrainian).

4. Коноплі: монографія (ред. Мигаль М.Д., Кабанец В.М.), Суми: Эллада, 2011, 384 p. (In Ukrainian).

5. Fuqua M. A., Huo S., Ulven C. A. Natural fiber reinforced composites. Polymer Reviews, 52 (3), 2012, pp. 259-320.

6. Delaney, T., Madigan, T. Beyond Sustainability: A Thriving Environment, McFarland \& Company, Inc., Publishers, Jefferson, North Carolina, 2014, pp.160-163.

7. Jankauskienė Z., Gruzdevienė E., Ivanovs S., Maumevičius E. Investigation of hemp (Cannabis sativa L.) morphological parameters as influenced by seed rate and genotipe. Engineering for rural development. Proceedings of 15th International Scientific Conference, May 25-27, 2016, Jelgava, Latvia. (Latvia University of Agriculture Faculty of Engineering), volume 15, pp. 893-897.

8. Ivanovs S.,Rucins A., Valainis O., Belakova D., Kirilovs E., Vidzickis R. Research of technological process of hemp slab production.Engineering for Rural Development, Proceedings, Volume 14, 2015. pp. 202-209. 
9. Jonaitienė V, Jankauskienė Z., Stuogè I. Hemp Cultivation Opportunities and Perspectives in Lithuania. Natural Fibres: Advances in Science and Technology Towards Industrial Applications From Science to Market (Editors: Raul Fangueiro, Sohel Rana), RILEM Bookseries, Volume 12, 2016, pp. 407-414.

10. Jankauskienè Z., Gruzdevienè E. Industrial hemp - a promising source for biomass production. Renewable Energy and Energy Efficiency. Proceedings of the international scientific conference, May 28-30, 2012, Jelgava, Latvia, Latvia University of Agriculture,Jelgava 2012, pp. 13-18.

11. McKendry P. Energy production from biomass (part 1): overview of biomass. Bioresource Technology, 83, 2002, pp. 37-46.

12. Buivydaitė V.V., Vaičys M., Juodis J., Motuzas A., Lietuvos dirvožemių klasifikacija (Classification of Lithuanian soils). Vilnius, 2001. p. 76. (in Lithuanian).

13. Tarakanovas P., Raudonius S. Agronominių tyrimų duomenų statistinė analizė taikant kompiuterines programas ANOVA, STAT, SPLIT-PLOT iš paketo SELEKCIJA ir IRRISTAT (Statistical analysis of agronomical research data with computer programs ANOVA, STAT, SPLIT-PLOT from packet SELEKCIJA and IRRISTAT). Akademija, Kauno r., 2003. 58 p. (in Lithuanian).

14. Poiša L., Adamovicšs A, Jankauskiene Z., Gruzdeviene E. Industrial hemp (Cannabis sativa L.) as a biomass crop. Treatment and use of organic residues in agriculture: challenges and opportunities towards sustainable management. Proceedings of the 14th Ramiran International Conference of the FAO ESCORENA Network on the Recycling in Agricultural, Municipal and Industrial Residues in Agriculture, Lisboa, Portugal, 12-15 September, 2010, pp. 326-330.

15. Komlajeva L.., Adamovičs, Poiša L. Comparison of different energy crops for solid fuel production in Latvia. Renewable Energy and Energy Efficiency. Proceedings of the international scientific conference, May 28-30, 2012, Jelgava, Latvia, Latvia University of Agriculture. Jelgava, 2012, pp. 45-50.

16. Streikus D., Jasinskas A., Arak M., Jotautienė E., Mieldažys R., Čekanauskas S., Jankauskienė Z. Investigations of fibre plants preparation and utilization of solid biofuels. Agronomy Research, 2016, 14 (1), pp. 259-268.

17. Cultivation and processing technology of industrial hemp (ed. Cierpucha W.). Poznan, 2013. $121 \mathrm{p}$. 